\title{
FABRICATION AND CHARACTERIZATION OF STARCH BASED BIOPLASTICS WITH PALM OIL ADDITION
}

\author{
Akbar Hanif Dawam Abdullah ${ }^{1}$, Anti Khoerul Fikriyyah ${ }^{\mathbf{1}}$ and Rahmad Dewantoro ${ }^{\mathbf{2}}$ \\ ${ }^{1}$ Loka Penelitian Teknologi Bersih - LIPI \\ Jalan Sangkuriang Komplek LIPI Gedung 50, Bandung, Indonesia 40135 \\ ${ }^{2}$ Departemen Fisika, Universitas Islam Negeri Sunan Gunung Djati Bandung \\ Jalan A H Nasution No. 105 Bandung, Indonesia 40614 \\ E-mail:akba001@lipi.go.id
}

Received: 4 January 2019

Revised: 20 March 2019

Accepted: 27 March 2019

\begin{abstract}
FABRICATION AND CHARACTERIZATION OF STARCH BASED BIOPLASTICS WITH PALM OIL ADDITION. In this work, starch-based bioplastics in advancing its properties were positively arranged with the addition of palm oil. Starch-based bioplastics were produced by dry blending method and compression technique with mixing starch and glycerol $(3: 1, \mathrm{w} / \mathrm{w})$ then adding palm oil at various concentration $(0 \%, 2.5 \%, 5 \%$ and $7.5 \% \mathrm{w} / \mathrm{w})$. Morphology of bioplastics presented that palm oil wrapped bioplastics granules which influenced hydrophobicity properties of bioplastics compared by increasing contact angle of bioplastics from $45.95^{\circ}$ ( $0 \%$ of palm oil) to $61.98^{\circ}$ (5\% of palm oil). This result indicated that the addition of palm oil could develop the properties of bioplastics to hold absorbing water molecules. Moreover, the melting point of bioplastics also affected shifting temperature from $115^{\circ} \mathrm{C}$ to be $100{ }^{\circ} \mathrm{C}$ that could save the energy needed during heating process. FTIR analysis showed that $\mathrm{C}=\mathrm{O}$ group at wavenumber $1747 \mathrm{~cm}^{-1}$ was dependable the interaction between starch-glycerol and palm oil. Furthermore, the addition of palm oil would accelerate the biodegradation process. Although the mechanical properties of bioplastics have not increased, the addition of palm oil on bioplastics fabrication is an alternative to improve the characteristic of bioplastics, especially physical, thermal, hydrophobicity and biodegradation properties.
\end{abstract}

Keywords: Bioplastics, Starch, Palm Oil, Characterizations

\begin{abstract}
ABSTRAK
FABRIKASI DAN KARAKTERISASI BIOPLASTIK BERBASIS STARCH DENGANADDITION MINYAK SAWIT. Dalam penelitian ini, bioplastik berbahan dasar pati dengan penambahan minyak kelapa sawit dilakukan untuk meningkatkan sifat bioplastik. Pembuatan bioplastik dilakuan dengan matode campur kering dan teknik kompresi dengan menambahkan pati dan gliserol $(3: 1, b / b)$ serta minyak kelapa sawit pada berbagai konsentrasi $(0 \%, 2,5 \%, 5 \%$ dan $7,5 \% \mathrm{~b} / \mathrm{b})$. morfologi bioplastik menunjukan palm oil menutupi granula bioplastik yang mempengaruhi sifat hidrofobisitas bioplastik dengan meningkatnya nilai sudut kontak bioplastik dari $45,95^{\circ}$ ( $0 \%$ minyak kelapa sawit) menjadi $61,98^{\circ}$ (5\% minyak kelapa sawit). Hasil tersebut menunjukan penambahan minyak kelapa sawit pada bioplastik dapat menahan molekul air. Selain itu, titik leleh bioplastik juga mengalami perubahan suhu dari $115^{\circ} \mathrm{C}$ menjadi $100^{\circ} \mathrm{C}$ yang berguna untuk menghemat energi yang dibutuhkan selama proses pembuatan bioplastik. Analisis FTIR menunjukkan bahwa gugus $\mathrm{C}=\mathrm{O}$ pada bilangan gelombang $1747 \mathrm{~cm}^{-1}$ merupakan ciriinteraksi antara pati-gliserol dan minyak kelapa sawit. Selain itu, penambahan minyak sawit akan mempercepat proses biodegradasi. Meskipun sifat mekanik bioplastik belum meningkat, minyak kelapa sawit pada bioplastik merupakan alternatif untuk meningkatkan karakteristik bioplastik, terutama sifat fisik, termal, hidrofobik dan biodegradasi.
\end{abstract}

Kata kunci: Bioplastik, Pati, Palm Oil, Karakterisasi 


\section{INTRODUCTION}

Bioplastics generally have been made from various types of natural sources such as starch, cellulose, protein etc. [1,2]. Starch is one type of natural polymers used in bioplastics manufacture since it is contained in the main food ingredients such as types of seeds and tubers. Starch has microcrystalline structures of amylose and amylopectin as main components for fabricating bioplastic because they have hard and sticky properties [3].

The advantages of starch-based bioplastics are biodegradable, biocompatible, eco-friendly and easily renewed $[2,4]$. Bioplastics are required to ensure characteristics like conventional plastics which are light, flexible, strong, transparent, and water resistant $[5,6]$. However, bioplastics from starch have disadvantages such as resistant to moisture which affect its properties, changes its shapes, reduce its mechanical properties, etc. $[7,8]$.

To overcome the disadvantages of starch, the addition of other materials into bioplastics has been carried out, such as mixing bioplastics with synthetic plastics [9,10], fiber [11], chitosan [12], lipids [13] etc. $[14,15]$. One type of lipids that is easily available is palm oil that has hydrophobic properties and resistant to high humidity. Some studies used residue of palm oil production that contain fiber combined with other components to make bioplastics [16,17]. But, utilization of fiber into bioplastic increase its mechanical properties recently.

Another study also used palm oil in the manufacture of bioplastics to rise its water barrier properties [18]. Liaotrakoon et al. (2018) managed of bioplastics research with palm oil addition and used Tween 80 by casting method [19]. In addition, Santoso et al. (2018) have also made edible films by added palm oil and Tween 20 as surfactants to bind starch and palm oil [20]. However, the addition of Tween 20 in the bioplastic fabrication process in industrial scale can increase the selling price of bioplastics so it is not efficient.

Therefore, fabrication of bioplastics from starch and palm oil addition through physical treatment using dry blending method and compression technique was conducted to determine the effect of adding palm oil to the properties of bioplastics. Based on previous research that has been done, the authors affirm that there has been no research about bioplastics fabrication with added palm oil using dry blending method and compression technique. Several tests have been carried out such as morphology, chemical, thermal, mechanical analysis, density measurement, water contact angle and biodegradability test. Furthermore, the addition of palm oil and the method used for bioplastics fabrication expectantly can improve the characteristics of bioplastics.

\section{MATERIALS AND METHODS}

\section{Materials and Equipment}

Cassava starch was made from extracting cassava tuber by using a method previously developed by minor modification [21] and glycerol was obtained from Merck, Germany. Then, palm oil was purchased from PT. Sinar Mas Agro Resources and Technology Tbk, Indonesia and potato dextrose agar (PDA) was bought from Himedia Laboratory, India. Furthermore, Aspergillus Niger as a microbe for biodegradability test was achieved from Research Centre for Biotechnology LIPI, Indonesia. Also, the equipment used in fabricating bioplastics are a Philips blender HR2118/01 with a power of $600 \mathrm{~W}$ and Compression molding from Toyoseki, Japan.

\section{Procedure}

To fabricate bioplastics, cassava starch was mixed with glycerol in a weight ratio of $3: 1$ and added palm oil at concentration $2.5 ; 5$; and $7.5 \%$ in respect of total weight. The mixture was processed by using blender for 3 minutes with dry blending method. After that, the blended materials were pressed by using compression molding at temperature of $130{ }^{\circ} \mathrm{C}$ for 15 minutes and pressured at $50 \mathrm{~kg} / \mathrm{cm}^{2}$ to form bioplastics films.

\section{Characterization}

Morphology analysis of bioplastics was obtained using a Jeol JSM-IT300 SEM (Japan) to establish the cross section of bioplastics with voltage of $20 \mathrm{kV}$. Then, chemical interaction of bioplastics was investigated using a Thermo Scientific Nicolet iS5 ATR-FTIR spectrometer (USA) with 64 rate scans. Thermal analysis was studied by a Netzsch 209 F1 Libra DSC (Germany) at temperature $40-150{ }^{\circ} \mathrm{C}$. Afterward, bioplastics were measured its mechanical properties by a universal testing machine (UCT-5T, Orientec Co. Ltd, Japan) with dumb bell JIS K7113-2-1/2 and the crosshead speed were $0.5 \mathrm{~mm} / \mathrm{min}$. The density of bioplastics was analyzed by using calibrated picnometer from PYREX and distillated water as immersing liquid. Also, water contact angle measurement was examined to know the hydrophobicity of bioplastics by dripping water onto bioplastics surface and determined the shaped angle using ImageJ software.

Additionally, biodegradability test was considered by a standard of ASTM G21-70 [22]. Distillated water of $10 \mathrm{~mL}$ sterilized by autoclave was appended into tube contained $A$. Niger then mixed by vortex to be $10^{\circ}$ solution. And the solvent of $10^{\circ}$ included A. Niger was taken $1 \mathrm{~mL}$ and dissolved into $9 \mathrm{~mL}$ of sterile distillated water to be $10^{-1}$ and it was repeated up to $10^{-2}$ dilution. After that, the dilution of $10^{-2}$ was removed as much as $100 \mu \mathrm{L}$ into the petri dish and it filled with 20 
mL PDA. Bioplastics with size $3 \times 3 \mathrm{~cm}$ were placed onto PDA surface. Then, the dilution of $10^{-2}$ were dripped about $50 \mu \mathrm{L}$ onto bioplastics and they were stored in an incubator at temperature of $30^{\circ} \mathrm{C}$ for 7 days.

\section{RESULT AND DISCUSSION}

Fabrication of bioplastics with the addition of palm oil using dry blending method and compression technique produced bioplastics sheets showed in Figure 1 .

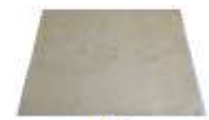

(a)

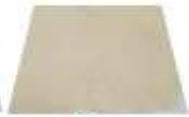

(b)

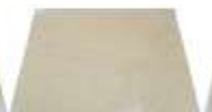

(c)

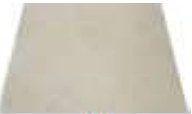

(d)
Figure 1. Starch based bioplastics with palm oil concentration of (a). $0 \%$, (b). $2.5 \%$, (c). $5 \%$ and (d). $7.5 \%$.

Bioplastics sheets visually created a yellowish color by adding palm oil into film, accordingly increasing palm oil concentration can affect bioplastics to have more yellow color, and palm oil also creates transparent color compared to bioplastics without including it [18]. In addition, palm oil made bioplastics to not easily stick with others and Palm oil also appointed bioplastics more dry because of the reduced water content due to the presence of palm oil [4]. To analyze deeply microstructures of bioplastics, SEM characterization was carried out to know the structure formed on the crosslink of bioplastics with palm oil clearly in Figure 2.
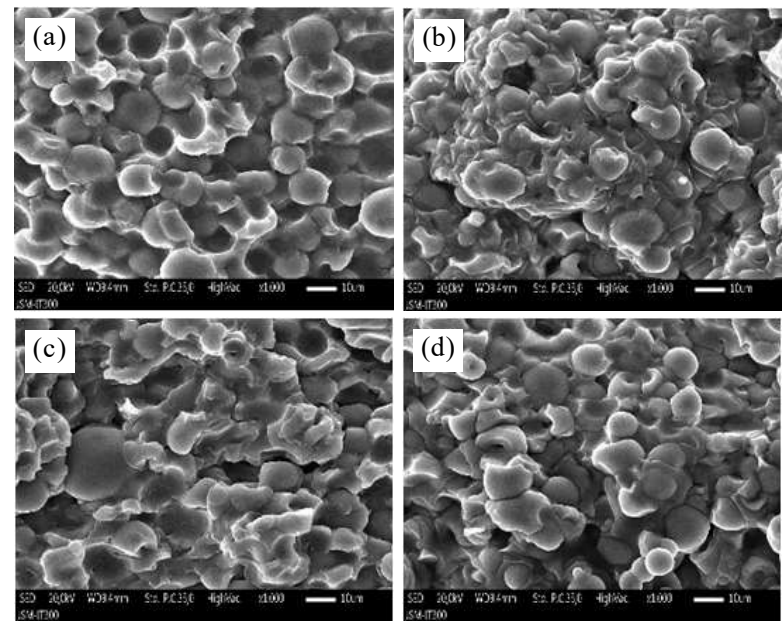

Figure 2. SEM images of bioplastics with palm oil concentrations of (a). $0 \%$, (b). 2.5\%, (c). $5 \%$ and (d). $7.5 \%$.

SEM images presented that bioplastics without palm oil (Figure 2 (a)) exhibited starch granules that are stuck to each other because of the gelatinization process between starch and glycerol affected by heating process during compression. Meanwhile, bioplastics with palm oil of 2.5 ; 5 ; and $7.5 \%$ (Figures 2 (b), (c) and (d)) showed starch granules that are covered by a layer indicating palm oil. Granulated starch also had irregular shapes compared to bioplastics without palm oil (Figure 2 (a)). Palm oil concentration of $2.5 \%$ in bioplastics also (Figure 2 (b)) formed an agglomeration and the surface of oil content chopped starch granules shapes. Then, bioplastics with palm oil of 5\% (Figure 2 (c)) appeared that palm oil covered the granules surface more prevalent and the starch granules have irregular shrub contours compared to the others. However, bioplastics with 7.5\% palm oil content (Figure 2 (d)) established the surface of starch granules which were not completely coated by palm oil and some granules were not adhered with glycerol or wrapped by palm oil.

The morphological appearance of bioplastics showed the more palm oil content was used, the less starch granules can be seen in bioplastics. The appearance of starch granules indicates the imperfect of gelatinization process, and it decreased with increasing palm oil. Nevertheless, the appearance of starch granules showed in bioplastics with palm oil content of $7.5 \%$ that the gelatinization process has not been completely enough. It might be because palm oil exceeds the optimum concentration that instigates lipid estrangement and heterogeneous structures [23]. To find out chemical interaction between starch and palm oil, FTIR spectrum can indicate chemical bonds of bioplastics as shown in Figure 3 .

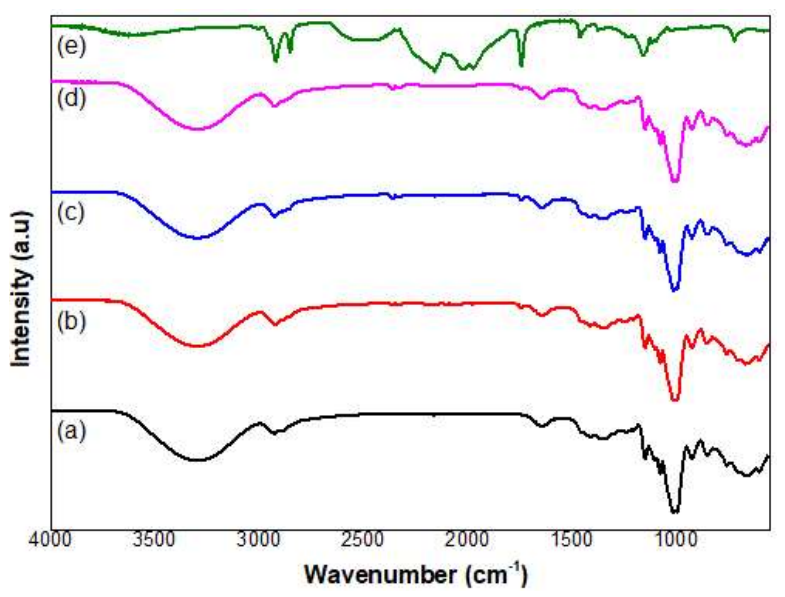

Figure 3. FTIR spectra of bioplastics with palm oil content of (a). $0 \%$, (b). $2.5 \%$, (c). $5 \%$, (d). $7.5 \%$ and (e). palm oil.

Palm oil of FTIR spectrum had aliphatic hydrocarbon bonds such as $-\mathrm{CH}_{3}$ at the area of $2951 \mathrm{~cm}^{-}$ ${ }^{1}$ and $1376 \mathrm{~cm}^{-1}$ then $-\mathrm{CH}_{2}$ at the area of $2852 \mathrm{~cm}^{-1}$ and $1476 \mathrm{~cm}^{-1}$. There also were occurred aliphatic ester bonds such as $-\mathrm{C}=\mathrm{O}$ in the area of $1743 \mathrm{~cm}^{-1}$ and $-\mathrm{C}-\mathrm{O}$ in the area of $1150 \mathrm{~cm}^{-1}$ that corresponded as the literature [24,25].

However, the results of FTIR characterization in bioplastics with the addition of palm oil $0 ; 2.5 ; 5$; and $7.5 \%$ showed the presence of aliphatic hydrocarbon such as $-\mathrm{CH}_{3}$ at wavenumber of $2926 \mathrm{~cm}^{-1}$ and $1337 \mathrm{~cm}^{-1}$; aliphatic alcohol such as $-\mathrm{O}-\mathrm{H}$ at wavenumber of 
$3298 \mathrm{~cm}^{-1}$ and $-\mathrm{C}-\mathrm{O}$ at wavenumber of $1078 \mathrm{~cm}^{-1}$; and aliphatic amides such as $-\mathrm{C}=\mathrm{O}$ bond at the area of $1645 \mathrm{~cm}^{-1}$. The chemical reaction between palm oil and bioplastics starch shows an intensity of $-\mathrm{C}=\mathrm{O}$ bond of aliphatic ester developed from palm oil in the area of $1747 \mathrm{~cm}^{-1}$. Palm oil has carbonyl stretching of the triacylglycerol ester linkage that could attach into starch based bioplastics because of gelatinization process [25]. However, there was no significant difference from the FTIR spectra of each bioplastic with increasing palm oil percentage. Based on this, the chemical interaction of palm oil was not fully connected with starch of bioplastics. This indicates that palm oil and starch formed physical interaction mostly as Liaotrakoon et al (2018) suggested that bioplastics with additional palm oil produced inhomogeneous mixtures [19].

To determine the thermal properties of bioplastics with the addition of palm oil, DSC graph was carried out as shown in Figure 4 to present the shifting temperatures melting towards the measurement of bioplastics mass.

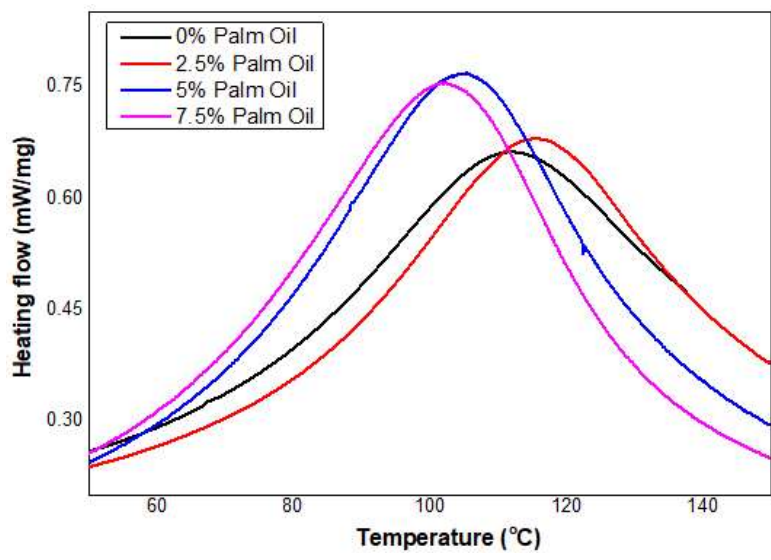

Figure 4. DSC thermal of bioplastics with palm oil content.

Bioplastics with the addition of palm oil had a melting temperature peak moved along with the rise of palm oil content. Bioplastics that had palm oil content of $0 \%$ and $2.5 \%$ showed the melting temperature peaks around $112-115{ }^{\circ} \mathrm{C}$. Then, bioplastics with palm oil content of $5 \%$ and $7.5 \%$ presented the melting peak close to temperature of $100{ }^{\circ} \mathrm{C}$. Melting temperature of bioplastics with palm oil content of $2.5 \%$ was shifted insignificantly compared with bioplastics without palm oil. On the other hand, increasing palm oil content made melting temperature point of bioplastics moved gradually. Nevertheless, heating flow of bioplastics rose by increasing palm oil. It means that the addition of palm oil can reduce melting temperatures of bioplastics because of the free volume created from dropping moisture content and changing the matrix of bioplastics thus increasing endothermic energy of bioplastics[19]. In addition, the melting temperature point of bioplastics can be one of the advantages in the process of bioplastics. This is related to the fabrication process which can reduce energy used in the gelatinization process of bioplastics with the addition of palm oil.

To measure the effect of palm oil on mechanical properties, bioplastics were tested using a tensile tester to determine the strength and elongation of bioplastics with the addition of palm oil. Figure 5 shows a diagram of tensile strength and elongation at break of bioplastics with the addition of palm oil.

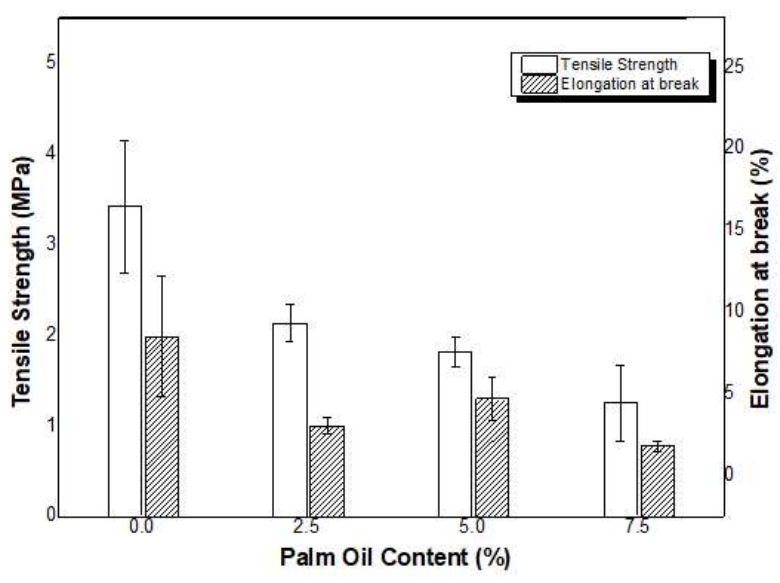

Figure 5. Tensile strength and elongation at break of bioplastics with different palm oil concentration.

Figure 5 presents that bioplastics without palm oil have better tensile strength and elongation at break than bioplastics with palm oil addition. Then, bioplastics with palm oil of $2.5 \% ; 5 \%$; and $7.5 \%$ have trivial elongation at break and reducing tensile strength by increasing palm oil. This is consisted with the study of Hawa et al. (2013) that presented the tensile strength and elongation at break of bioplastics with palm oil addition decreased by using casting method [4]. Palm oil contains liquid unsaturated fatty acids that have mobility of their double bonds, so it distributes on bioplastics matrices [26]. However, the field between palm oil and bioplastics gives defects because of inhomogeneous structures such as weak interfacial affection between lipid and polymer [27]. In addition, lipids have disadvantages that are brittle and inelastic because of reduced moisture, so bioplastics have reduction of tensile strength and elongation at break [28]. To know hydrophobicity and molecular weight of bioplastics by adding palm oil, the density and water contact angle test also identified as shown in Table 1.

Table 1. Density and water contact angle results of bioplastics with the addition of palm oil.

\begin{tabular}{cccc}
\hline $\begin{array}{c}\text { Starch : } \\
\text { Glycerol }\end{array}$ & $\begin{array}{c}\text { Palm Oil } \\
\text { Content }(\%)\end{array}$ & $\begin{array}{c}\text { Density } \\
\left(\mathrm{g} / \mathrm{cm}^{3}\right)\end{array}$ & $\begin{array}{c}\text { Contact Angle } \\
\left({ }^{\circ}\right)\end{array}$ \\
\hline $3: 1$ & 0 & $1.39 \pm 0.08$ & $45.95 \pm 0.02$ \\
$3: 1$ & 2.5 & $1.38 \pm 0.07$ & $46.83 \pm 0.52$ \\
$3: 1$ & 5 & $1.31 \pm 0.01$ & $61.98 \pm 0.23$ \\
$3: 1$ & 7.5 & $1.33 \pm 0.03$ & $49.46 \pm 0.6$ \\
\hline
\end{tabular}

The density of bioplastics with palm oil addition decreases because palm oil has lower density than starch 
or glycerol. The density of bioplastics without palm oil is higher than bioplastics by adding palm oil. Then, the density of bioplastics with palm oil $2.5 \%$ is negligible with bioplastics without palm oil. Also, bioplastics with palm oil $5 \%$ and $7.5 \%$ have indifference density. Decreasing density of bioplastics is one of the advantages in the construction of bioplastics, because the conventional plastics commonly have mild polymer and lower density.

On the other hand, the water contact angle test shows insignificant changes between bioplastics without palm oil and $2.5 \%$ palm oil content. Also, contact angle of bioplastics with $5 \%$ palm oil increased to be $61.98^{\circ}$ and bioplastics with $7.5 \%$ palm oil decreased to be $49.42^{\circ}$. it means that the addition of palm oil can improve the hydrophobicity of bioplastic even though the degrees could not reach $90^{\circ}$ [29]. Moreover, the results are parallel with SEM characterization where the surface of $5 \%$ palm oil is wrapped by palm oil and bioplastics of $7.5 \%$ palm oil have a structure where starch granules could be seen that means incomplete gelatinization, so the water molecules can be absorbed easily. Some researches included surfactants such as Tween 20 and Tween 80 to increase the bonds between starch and palm oil so that the hydrophobicity of bioplastics could rise gradually $[17,18]$.

In addition, biodegradation tests were also carried out by Table 2 confirmed the results of biodegradation test for bioplastics using Aspergillus Niger sp. and media of Potato Dextrose Agar. The results show that palm oil supplement of bioplastics increased $A$. Niger growth. Visually, bioplastics with $0 \%$ palm oil leave a surface that has not been covered by A. Niger. after incubation for seven days.

Table 2 . The biodegradability test of bioplastics with differentiation of palm oil.

\begin{tabular}{|c|c|c|c|c|}
\hline \multirow{2}{*}{ Day } & \multicolumn{4}{|c|}{ Palm Oil Content } \\
\hline & $0 \%$ & $2.5 \%$ & $5 \%$ & $7.5 \%$ \\
\hline 0 & & & & \\
\hline 1 & & & & \\
\hline 2 & & & & \\
\hline 4 & & & & \\
\hline 7 & & & & \\
\hline
\end{tabular}

Meanwhile, bioplastics with additional palm oil produce a surface completely covered after an incubation process for seven days. This shows that the addition of palm oil enhances the degradation process of bioplastics. Starch is a food source for A. Niger, so when bioplastics are added with palm oil, the starch content in the bioplastic matrix would be reduced due to the presence of palm oil. This shows that the addition of palm oil makes it easy for bioplastics to be degraded quickly.

\section{CONCLUSION}

The mixture of starch based bioplastics with palm oil using dry blending method and compression technique has several advantages, especially in physical, thermal, hydrophobicity and biodegradation properties. Bioplastics have a lower density value by adding palm oil to be lighter bioplastics, especially in the content of $5 \%$ palm oil with a density value of $1.31 \mathrm{~g} / \mathrm{cm}^{3}$. Furthermore, the melting temperature of bioplastics reduced with increasing palm oil content, so it can save energy usage during the bioplastic process. Bioplastics with palm oil addition are also able to improve the biodegradation process so that there is no accumulation of waste in long periods.

\section{ACKNOWLEDGMENT}

This work was supported by Ministry of Research, Technology and Higher Education of Republic of Indonesia, Insinas Project fiscal year 2018.

\section{REFERENCES}

[1]. R. F. T. Stepto, "Thermoplastic Starch," Macromol. Symp., vol. 152, pp. 73-82, 2000.

[2]. M. Kaseem, K. Hamad, and F. Deri, "Thermoplastic starch blends: A review of recent works," Polym. Sci. Ser. A, vol. 54, no. 2, pp. 165-176, 2012.

[3]. H. B. Lee, B. S. Noh, and S. C. Min, "Listeria monocytogenes inhibition by defatted mustard meal-based edible films," Int. J. Food Microbiol., 2012.

[4]. L. T. Hawa and I. Thohari, "Pengaruh pemanfaatan jenis dan konsentrasi lipid terhadap sifat fisik edible film komposit whey-porang," J. Ilmu-Ilmu Peternekan, vol. 23, no. 1, pp. 35-43, 2013.

[5]. S. Aripin, B. Saing, and E. Kustiyah, "Studi Pembuatan Bahan Alternatif Plastik Biodegradable dari Pati Ubi Jalar dengan Plasticizer Gliserol dengan Metode Melt Intercalation," J. Tek. Mesin, vol. 06, pp. 79-84, 2017.

[6]. Y. R. Hasanah and Haryanto, "Pengaruh Penambahan Filler Kalsium Karbonat (CaCO3) Dan Clay Terhadap Sifat Mekanik Dan Biodegradable Plastik Dari Limbah Tapioka," Techno, vol. 18, no. 02,pp. 96-107, 2017. 
[7]. J. A. Mbey, S. Hoppe, and F. Thomas, "Cassava starch-kaolinite composite film. Effect of clay content and clay modification on film properties," Carbohydr. Polym., vol. 88, no. 1, pp. 213-222, 2012.

[8]. Waryat, M. Romli, A. Suryani, I. Yuliasih, and S. J. A. Nasiri, "Pemanfaatan Pati Termoplastik Sebagai Bahan Baku Plastik Kemasan Ramah Lingkungan," Bul. Pertan. Perkota., vol. 4, no. 1, pp. 37-48, 2014.

[9]. K. S. Lim et al., "A review of application of ammonium polyphosphate as intumescent flame retardant in thermoplastic composites," Compos. Part B Eng., 2016.

[10]. N. St-Pierre, B. D. Favis, B. a Ramsay, J. a Ramsayt, and $\mathrm{H}$. Verhoogt, "Processing and characterization of thermoplastic starch / polyethylene blends," Polymer (Guildf)., vol. 38, no. 3, pp. 647-655, 1997.

[11]. A. K. Bledzki and J. Gassan, "Composites reinforced with cellulose based fibres," Prog. Polym. Sci., 1999.

[12]. C. Zhuang et al., "Development and characterization of nano-bilayer films composed of polyvinyl alcohol, chitosan and alginate," Food Control, vol. 86, pp. 191-199, 2018.

[13]. Fauziati, Y. Adiningsih, and A. Priatni, "Pemanfaatan stearin kelapa sawit sebagai edible coating buah jeruk," J. Ris. Teknol. Ind., vol. 10, no. 1, pp. 64-69, 2016.

[14]. P. Putro, "Kemasan Edible Antimokroba dan Aplikasinya," pp. 73-79, 2013.

[15]. B. Santoso, "Development of Edible Film by Using Modified Cross-Linking Ganyong Starch," J. Teknol. Dan Ind. Pangan, no. Vol 22, No 2 (2011): Jurnal Teknologi dan Industri Pangan, p. 105, 2011.

[16]. H. D. Rozman, A. Zainal, M. Ishak, and U. S. Ishiaku, "Oil Palm Fiber-Thermoplastic Composites," in Natural fibers, biopolymers, and biocomposites, 2005, pp. 407-434.

[17] Ridwansyah, M. Z. Nasution, T. C. Sunarti, and A. M. Fauzi, "Karakteristik Sifat Fisiko-Kimia Pati Kelapa Sawit," J. Teknol. Ind. Pertan., vol. 17, no. 1, pp. 1-6, 2007.

[18] Harianto, J. M. Djafar, and H. Adinegoro, "Pengaruh penambahan minyak sawit terhadap karakteristik edible film dan daya simpan bumbu mie instant," J. Stand., vol. 19, no. 1, pp. 39-46, 2017.
[19]. V. Liaotrakoon and P. Raviyan, "Modifying the properties of whey protein isolate edible film by incorporating palm oil and glycerol," vol. 40, no. 1, pp. 243-249, 2018.

[20]. B. Santoso, D. Amilita, G. Priyanto, H. Hermanto, and S. Sugito, "Pengembangan Edible Film Komposit Berbasis Pati Jagung dengan Penambahan Minyak Sawit dan Tween 20," Agritech, vol. 38, no. 2, p. 119, 2018.

[21]. K. Kaur, P. Ahluwalia, and H. Singh, "Cassava: Extraction of starch and utilization of flour in bakery products," Int. J. Food Ferment. Technol., vol. 6, no. 2, p. 351, 2017.

[22]. Made Dirgantara, Miko Saputra, "Karakterisasi Mekanik Biokomposit Klobot Jagung Sebagai Bahan Dasar Plastik Biodegradable,” 2017.

[23]. M. Chiumarelli and M. D. Hubinger, "Stability, solubility, mechanical and barrier properties of cassava starch - Carnauba wax edible coatings to preserve fresh-cut apples," Food Hydrocoll., 2012.

[24]. A. G. Peña et al., "Fourier transform infraredattenuated total reflectance (ftir-atr) spectroscopy and chemometric techniques for the determination of adulteration in petrodiesel/biodiesel blends," Quim. Nova, vol. 37, no. 3, pp. 392-397, 2014.

[25]. Y. B. Che Man, A. M. Marina, A. Rohman, H. A. AlKahtani, and O. Norazura, "A fourier transform infrared spectroscopy method for analysis of palm oil adulterated with lard in pre-fried french fries," Int. J. Food Prop., vol. 17, no. 2, pp. 354-362, 2014.

[26]. B. Santoso, F. Pratama, B. Hamzah, and R. Pambayun, "Pengembangan Edebli Film dengan Menggunakan Pati Ganyong Termodifikasi Ikatan Silang," J. Teknol. dan Ind. Pangan, vol. XXII, no. 2, pp. 105-109, 2011.

[27]. P. Zhang, Y. Hu, L. Song, J. Ni, W. Xing, and J. Wang, "Effect of expanded graphite on properties of high-density polyethylene/paraffin composite with intumescent flame retardant as a shapestabilized phase change material," Sol. Energy Mater. Sol. Cells, 2010.

[28]. H. Park, "Edible Coatings and Films to Improve Food Quality," Trends Food Sci. Technol., 1995.

[29]. G. Bracco and B. Holst, Surface science techniques, vol. 51, no. 1. 2013. 